\title{
Teaching Philosophy
}

\author{
Faisal Ameen
}

Aga Khan University School of Nursing and Midwifery

\begin{abstract}
Teaching strategies play a key role in student performance, as mostly students were confused initially in the studies and this can be reduce only if the teachers used sound strategies for their students. According to Plato, knowledge cannot be transfer from teacher to student but rather education consist in direct students mind, towards what is real and important and allowing them to apprehend it for themselves (Uzun, 2014). There are number of teaching strategies exists inside and outside of the classroom in which discussion is also one of them Hence research also proves that no matter teaching continue on online or a class room based, importance of discussion will remain same. In addition there is considerable educational literature suggest that, student's achievement are relate d to their way of learning (Marton \& Booth, 1997).
\end{abstract}

Keywords: Teaching philosophy, teaching strategies, importance of teaching strategies, Teaching and learning

\section{Introduction}

According to Plato, knowledge cannot be transfer from teacher to student but rather education consist in direct students mind, towards what is real and important and allowing them to apprehend it for themselves (Uzun , 2014) we all have an innate curiosity built-in, in our nature and for this we question and try to find out, our answers. Knowledge is incomplete without having the sense of philosophy, which results in new queries, problems and even counterparts as long as the discussions continue. (Durmus, 2014). To my way of thinking teaching learning strategies should be multifarious and malleable, because it gives opportunity to the students to think judgmentally, and comprehension knowledge according to their own proficiency. In addition, my teaching philosophy explains that teacher should use discussion method as a strategy in their teaching method, because it gives scaffolding to the students to thinking out of the box. Moreover, a virtuous and proficient teacher is one who creates a diversity and healthy learning environment for their students. I have attempted to construe my teaching learning philosophy from multidimensional context in this paper, likewise being students, being a teacher, from teaching perspectives and I have also share my views on , how empowering teaching learning environment.

\section{Students}

I believe that Discussion is essential part for students from teaching learning aspects, because its gives selfdetermination to the students to enlighten their views and ideas from diverse prospective. More over by providing discussion forum, from the teachers to the students, they can flourish learners mind and thoughts in a sophisticated manner, especially when we talk about in online context. (Raees, 2013).In my point of view whatever the strategy teacher uses, it should be built on two way communication. As I have mention in above paragraph that teaching requires improvement and resilience to deal with different circumstances, but the importance of discussion will remain same whether it's based on online learning or class room.

Furthermore there is certain criterion of the online discussion as well, according to the Raees 2013, facilitator should involve each participants in discussion at least once, and should engage in ongoing conversation with several participants. As the matter of fact now a days teaching is different from the past decade due to integration of online learning into education. Moreover learning is not only limited to the classroom but outside the classroom as well. Hence research also proves that no matter teaching continue on online or a class room based, importance of discussion will remain same. In addition there is considerable educational literature suggest that, student's achievement are related to their way of learning (Marton \& Booth, 1997). Research shows that now a days the role of the teacher is far behind of the traditional style of transfer knowledge, to give the best knowledge to the students teacher apply different strategies in which discussion is also one of them (Isabe , et.al 2008). I believe that discussion can play an essential role in student's professional as well as personal life too; moreover professional development is also a complex process, which should be seen as a lifelong activity that does not end when students will finish their studies. (Hallin \& Danielson, 2008) if they develop this skill in their personality it will help them to implement that skill in the clinical areas too. If talk about the importance of discussion in clinical context, then we realize that those nurses who develop the habit of discussion in their personality, are more confident in reasoning comparatively to those, whom doesn't have the habit of discussion. A qualitative study conducted in Sweden in 2011, in which researcher took three groups, and when analyzing the result of the three groups of nurses, One group that differed from the others was the taskoriented group, and the group of that nurses were involved in discussions.

\section{Teachers}

To my way of thinking discussion is a strategy which is not only important for student, but also for teachers. We cannot deny from this fact that every students have different learning capacity because they belongs form different educational and cultural background, and this thing leads to their level of understanding as well, But once students get admission in the school, college and even university, then it is in teachers hand how they educate them. I believe that discussion is the strategy through which teacher empower the student, and gave them confidence. Researches shown that, now a teachers in higher education demands a strong commitment on understanding the students learning process 


\section{International Journal of Science and Research (IJSR) \\ ISSN (Online): 2319-7064}

Index Copernicus Value (2015): 78.96 | Impact Factor (2015): 6.391

and strategies, and they aiming to supervise the students construction of knowledge, since year one (Isabe, et.al 2008). As far as my thinking, the reason behind these phenomena is that, teacher wants to develop the habit of discussion in their students, so that they will not face problem when they come in professional life. In addition Children's social development and problem-solving skills are also enhanced with the help of discussion strategy. (Tzuo \& Chen, 2011). Furthermore, I also consider that teachers should give equal chance to every student to speak and take part in discussion, because this practice make them prefect, and can help them out once they come in professional life. Research shows that with the help of discussion with class fellows and teachers, students achieve desired learning outcomes and gratification. (Prince 2004). Moreover useful discussion also helps to the students to develop oral communication skills and develops critical thinking skills. (Dallimore, Hertenstein, and Platt 2008). Mostly people think that discussion strategy is useful only in small group but according to the study of university of central Florida, Our research students can receive the salutary effects of discussions even in larger classes through discussions in the class. (Philip, Kerstin \& Bruce, 2011).

\section{Learning}

I believe that Students take, faculty members as a role model. They learn better and adopt every single aspect of teachers. When teacher spectacle certain attribute by practicing himself, it really matters a lot for their students. A strong relationship is necessary for effective learning, between teachers and students. Student's satisfaction with specific characteristics of the learning environment appears to be a critical factor. Multiple strategies also have the advantages of appealing to all types of learner (Billings \& Halsted, 2012). As I have explained my philosophy in previous paragraph that discussion plays an important role in students learning. Teacher can used discussion as a strategy in problem based learning as well. In this way in one hand students get knowledge and on the other hands they would gain the self-confidence too. Furthermore if teacher use discussion as a strategy then he would come to know the strength and weakness of his students as well, in other way besides the learning, teachers can apprise to the students on the bases of class performance. However teachers can also give instructions to the students to learn the content independently through readings, online lectures, and an online quiz, before coming in the class, this activity can reduce the time in class and students can participate in better way in discussion..

\section{Learning Environment}

Student satisfaction is the subjective perceptions, on student's part of how well a learning environment supports academic success. Academic success relies on certain features of learning environments as well. The major goal is to prepare better graduates for the current and future health care environments. Moreover in any institution infrastructure is also play an important part on students learning for example classroom, computer lab, skills lab, and library these are all the important building blocks on which the whole institutions is based. Similarly in addition ground rules for one teacher is also subject of matters on students learning and can effect on learning environment. If I would be a teacher then I select certain rules for my class as well likewise, give proper chance to every student to take part in discussion class activity, and do not allow coming inside the class after $10 \mathrm{~min}$ because other students will get suffer. I believe that all the teacher have the basic aim, which is to provide effective teaching and learning environment to the students.

\section{References}

[1] Andersson, N., Klang, B., \& Petersson, G. (2012). Differences in clinical reasoning among nurses working in highly specialised paediatric care. Journal of clinical nursing, 21(5-6), 870-879.

[2] Billings, D. M., \& Halstead, J. A. (2013). Teaching in nursing: A guide for faculty. Elsevier Health Sciences.

[3] Dallimore, E. J., Hertenstein, J. H., \& Platt, M. B. (2008). Using discussion pedagogy to enhance oral and written communication skills. College Teaching,56(3), 163-172.

[4] Huet, I., Tavares, J., Costa, N., Jenkins, A., Ribeiro, C., \& Baptista, A. V. (2008). Strategies to promote effective learning and teaching in higher education: A Portuguese perspective. The International Journal of Learning, 15(10), 157-164.

[5] Hamann, K., Pollock, P. H., \& Wilson, B. M. (2012). Assessing student perceptions of the benefits of discussions in small-group, large-class, and online learning contexts. College Teaching, 60(2), 65-75.

[6] Pollock, P. H., Hamann, K., \& Wilson, B. M. (2011). Learning through discussions: Comparing the benefits of small-group and large-class settings.Journal of Political Science Education, 7(1), 48-64.

[7] Robinson, B. K., \& Dearmon, V. (2013). Evidencebased nursing education: Effective use of instructional design and simulated learning environments to enhance knowledge transfer in undergraduate nursing students. Journal of Professional Nursing, 29(4), 203209.

[8] Teaching/Learning Strategies through Art: Philosophy \& Basic Design Education Serap Durmusa a PhD., Karadeniz Technical University, Department of Architecture, Faculty of Architecture, Trabzon,

[9] Tzuo, P. W., \& Chen, D. T. (2011). Re-Conceptualizing Teacher Authority: When to Exact. New Horizons in Education, 59(1), 1-11.

[10]UZUN, L. (2014). Raising awareness of educational philosophy: learning and education in posthumanistic philosophy. Journal of Theory and Practice in Education, 10(3), 613-626. 